\title{
Entrepreneurship and the Economics of the Firm
}

\author{
Foss, Nicolai J.; Klein, Peter G.; Bylund, Per L.
}

Document Version

Final published version

Publication date:

2011

\section{License \\ CC BY-NC-ND}

Citation for published version (APA):

Foss, N. J., Klein, P. G., \& Bylund, P. L. (2011). Entrepreneurship and the Economics of the Firm. Institut for Strategic Management and Globalization. SMG Working Paper No. 6/2011

Link to publication in CBS Research Portal

\section{General rights}

Copyright and moral rights for the publications made accessible in the public portal are retained by the authors and/or other copyright owners and it is a condition of accessing publications that users recognise and abide by the legal requirements associated with these rights.

\section{Take down policy}

If you believe that this document breaches copyright please contact us (research.lib@cbs.dk) providing details, and we will remove access to the work immediately and investigate your claim. 
Entrepreneurship and the Economics of the Firm

Nicolai J. Foss

Peter G. Klein

Per L. Bylund

SMG WP 6/2011

January, 2011 
SMG Working Paper No. 6/2011

January, 2011

ISBN: 978-87-91815-68-3

Department of Strategic Management and Globalization Copenhagen Business School

Porcelænshaven 24

2000 Frederiksberg

Denmark

www.cbs.dk/smg 


\title{
ENTREPRENEURSHIP AND THE ECONOMICS OF THE FIRM
}

\author{
Nicolai J. Foss \\ Department of Strategic Management and Globalization, Copenhagen Business School, \\ Porcelainshaven 24, DK-2000 Frederiksberg, Denmark; njf.smg@cbs.dk \\ and \\ Department of Strategy and Management, Norwegian School of Economics and Business \\ Administration, Breiviksveien 40, N-5045, Bergen, Norway. \\ Peter G. Klein \\ Division of Applied Social Sciences, University of Missouri, 135D Mumford Hall \\ Columbia MO 65211, USA; pklein@missouri.edu. \\ Per L. Bylund \\ Division of Applied Social Sciences, University of Missouri, 135D Mumford Hall \\ Columbia MO 65211, USA; per.bylund@mail.mizzou.edu
}

January 19, 2011

Prepared for Daniel Hjorth, ed.

Handbook of Organisational Entrepreneurship. Edward Elgar.

Keywords: The theory of the firm, entrepreneurship, Austrian economics

JEL Code: D23, B53 


\title{
ENTREPRENEURSHIP AND THE ECONOMICS OF THE FIRM
}

\begin{abstract}
the study of entrepreneurship and the study of economic organizing lack contact. In fact, the modern theory of the firm virtually ignores entrepreneurship, while the literature on entrepreneurship often sees little value in the economic theory of the firm. In contrast, we argue in this chapter that entrepreneurship theory and the theory of the firm can be usefully integrated, and that doing so would improve both bodies of theory. Adding the entrepreneur to the theory of the firm provides a dynamic view that the overly static analysis of firm organizing cannot support. Moreover, adding the firm to the study of the entrepreneur provides important clues to how we can understand entrepreneurship.
\end{abstract}




\section{INTRODUCTION}

What is the relationship between entrepreneurs and business firms? Do entrepreneurs need firms to carry out their function, and do firms need entrepreneurs to survive in the competitive market process? What exactly do entrepreneurs do inside firms - establish, finance, direct, control, operate? Does the entrepreneur disappear from stage once the firm is founded, handing things off to professional managers who do not merit the label “entrepreneur"? These questions strike simultaneously at the hearts of microeconomics and management research in entrepreneurship (cf. Shane and Venkataraman 2000). And yet the study of entrepreneurship and the study of economic organizing lack contact. In fact, the modern theory of the firm virtually ignores entrepreneurship, while the literature on entrepreneurship often sees little value in the economic theory of the firm ( $\mathrm{N}$. J. Foss and Klein 2005).

This divide emerged as microeconomic analysis took important steps toward increased scientific rigor, which in effect left no room for dynamic elements such as entrepreneurs or entrepreneurship. The economic theory of the firm was subsumed into neoclassical price theory (O'Brien 1984) and reformulated using game theory and the economics of information (N. J. Foss and Klein 2011). As a result, modern contributions to the theory of the firm (Williamson 1975; 1985; 1996; Milgrom and Roberts 1992; Hart 1995) focus on solving given optimization problems and are therefore typically static and “closed.” They tend to avoid open-ended questions about where the problems come from or what is the origin of the firm. Indeed, the question of firm emergence in the market place is almost completely left out of the theoretical discourse on the firm.

In contrast, we argue in this chapter that entrepreneurship theory and the theory of the firm can be usefully integrated, and that doing so would improve both bodies of theory. Adding the entrepreneur to the theory of the firm provides a dynamic view that the overly static analysis of firm 
organizing cannot support. Moreover, adding the firm to the study of the entrepreneur provides important clues to how we can understand entrepreneurship.

We begin by briefly surveying the study of entrepreneurship in the economics and management literatures and ask to what extent the entrepreneur, characterizes in the most common ways, needs a firm. We focus on entrepreneurship as judgment, a view we trace to Richard Cantillon, Frank Knight, and Ludwig von Mises and has a direct and natural link to the theory of the firm: the entrepreneur needs a firm because judgment cannot be purchased on the market. Next, we review the main themes in the modern theory of the firm and strategic entrepreneurship, and show how entrepreneurship as judgment illuminates these issues in novel and theoretically useful ways.

In the concluding parts of the chapter, we point to the fact that resources, in contrast to the common treatment in economic theory, are fundamentally heterogeneous (Lachmann [1956] 1978) and therefore that resource uses are not simply data but are created as entrepreneurs envision new ways of using assets to produce goods. We make the further case that asset ownership through a firm allows the entrepreneur to experiment with novel combinations of these heterogeneous assets and thus provides a vehicle through which the entrepreneur can attempt to realize imagined production structures. From this approach a number of unconventional insights emerge, which may prove useful in further theorizing on the firm and entrepreneurship.

\section{ENTREPRENEURSHIP: OUTCOME OR ACTION?}

Entrepreneurship comes in many shapes and forms, all of which are not relevant to or can usefully be linked to the theory of the firm. We find it useful to distinguish between theories or approaches that define entrepreneurship as an outcome or a phenomenon (self-employment, startup companies) and those that see it as a way of acting or thinking (creativity, innovation, alertness, judgment, adaptation) (cf. Klein 2008; Casson 1982; Knight 1942). Some “outcome” approaches 
deal with firms — e.g., what is the ratio of small ones to large ones in an industry or economy—but the decision to limit "entrepreneurial” behavior to small or new firms is unnecessarily restrictive, and not closely connected to the classic contributions to the economic theory of entrepreneurship associated with Knight, Schumpeter, Kirzner, and others. “Action” approaches, what Klein (2008) calls "functional" concepts of entrepreneurship, are more useful in linking to the theory of the firm.

The economic function of the entrepreneur has been characterized in various ways: judgment, innovation, alertness, adaptation, coordination, and so on. Whereas all these functional approaches are interesting and have advantages, the notion of entrepreneurship as judgment has particularly important implications for the analysis of the business firm. Schumpeter's idea of entrepreneurship as innovation ([1911] 1934) helps illuminate the process by which industries and economies expand and contract, but Schumpeter treats the entrepreneur as an uncaused cause, a pure genius who operates outside the usual constraints imposed by resource owners and other market participants and is largely independent of the firm. Kirzner's (1973; 1979; 1992; 2009) conception of entrepreneurship as “alertness" to or the discovery of profit opportunities, building on Hayek’s (1978) view of competition as a “discovery procedure," attempts to elucidate the equilibrating character of the market process. Like Schumpeter’s entrepreneur, however, Kirzner’s discoverer does not work with firms; the Kirznerian entrepreneur does not own capital and is not subject to losses, and hence does not need a firm to exercise his function in the economy (N. J. Foss and Klein forthcoming). The coordinating entrepreneur communicates "mental models" of reality (Casson 2000) to be adopted by others, thereby creating a shared vision through which production is coordinated. This view of entrepreneurship as “cognitive leadership” (Witt 1998; 1999) focuses almost exclusively on human resources and firm organizing relies on establishing a tacit, shared framework of goals to govern relationships among members of the entrepreneur's team. Even though charismatic leadership may be seen as a coordinating force, it is not clear why such is more 
entrepreneurial than other kinds of leadership or mundane managerial tasks. It is furthermore unclear in what sense the charismatic leader is primarily an economic agent and how sharing of a vision characterizes a firm.

\section{ENTREPRENEURSHIP AS JUDGMENT}

In contrast, the view of entrepreneurship as consisting of judgmental decision-making under conditions of uncertainty (Casson 1982; Langlois and Cosgel 1993; N. J. Foss and Klein 2005; cf. Cantillon [1755] 2010) maps more naturally into theories of business strategy and organization. Judgment refers to business decision-making when the range of possible future outcomes, as well as the likelihood of individual outcomes, is unknown (what Knight ([1921] 1985) terms uncertainty, rather than mere probabilistic risk). Uncertainty bearing is the entrepreneur's raison d'être. As Mises (1949, p. 252) puts it, "the outcome of action is always uncertain. Action is always speculation.” Consequently, “the real entrepreneur is a speculator, a man eager to utilize his opinion about the future structure of the market for business operations promising profits. This specific anticipative understanding of the conditions of the uncertain future defies any rules and systematization” (1949, p. 585).

Judgment is distinct from boldness, innovation, alertness, and leadership, and must be exercised in mundane circumstances, for ongoing operations as well as new ventures. While alertness tends to be passive, and perhaps even hard to distinguish from luck (Demsetz 1983), judgment is active. Entrepreneurs "are those who seek to profit by actively promoting adjustment to change. They are not content to passively adjust their . . . activities to readily foreseeable changes or changes that have already occurred in their circumstances; rather, they regard change itself as an opportunity to meliorate their own conditions and aggressively attempt to anticipate and exploit it” 
(Salerno 1993, p. 123). Those who specialize in judgmental decision-making may be dynamic, charismatic leaders, but they need not possess these traits. Decision making under uncertainty is entrepreneurial, whether it involves imagination, creativity, leadership, and related factors or not.

While the view of entrepreneurship as judgment appears in many writers, it is most often associated with Knight ([1921] 1985), who introduces the concept to explain profit and the firm through the existence of uncertainty. For Knight, firm organization, profit, and the entrepreneur are closely related; they arise as an embodiment, a result, and a cause, respectively, of commercial experimentation (Demsetz 1988a). Businessmen use their judgment, a learned trait with a large tacit component, to form estimates of future events in situations where there is no agreement or idea at all on probabilities of occurrence. Entrepreneurship, the exercise of judgmental decision-making, therefore cannot be assessed in terms of its marginal product and cannot be paid a wage, which means there can be no market for judgment. This is particularly because entrepreneurship is judgment about the most uncertain events, such as starting a new firm, defining a new market, and the like. The lack of basis for market pricing suggests that exercising judgment requires the person with judgment to start a firm. Consequently, judgment implies asset ownership. Judgmental decision-making is ultimately decision-making about the allocation and employment of resources; a decision-maker without capital goods cannot, to Knight, be an entrepreneur. Indeed, entrepreneurial decision making without asset ownership constitute "mere parlor games until the money is obtained and committed to the projects” (Rothbard [1985] 1997, p. 283).

There is therefore an obvious link between entrepreneurship and the theory of the firm, particularly those that define asset ownership as a crucial ingredient of firm organization (Hart 1995; Williamson 1996). The firm, in this sense, is the entrepreneur and the alienable assets he owns and ultimately controls_-structured, specialized, and combined to attain the entrepreneur's imagined end. The theory of the firm is essentially a theory of how the entrepreneur exercises his 
judgmental decision-making — what combinations of assets he seeks to acquire, what (proximate) decisions he delegates to subordinates, how he provides incentives and employ monitoring to see that his assets are used consistently with his judgments, and so on.

\section{DOES THE FIRM NEED AN ENTREPRENEUR?}

Some concepts of entrepreneurship, and especially entrepreneurship as judgmental decision making under uncertainty, have implications for resource ownership, and consequently for the formation and organization of firms. But this does not suggest how entrepreneurship is best incorporated into the theory of the firm, and it also does not provide sufficient clues for the role of the entrepreneuror whether the entrepreneur is necessary for economic organization. To formulate a theoretically viable relationship between the firm and entrepreneurship, we need to look more closely to the various established theories of the firm and explore how they explain what constitutes a firm and how firm organizing fosters decision making.

As modern, “neoclassical” economics emerged in the mid-to-late twentieth century, the firm was given "an increasingly passive role” (McNulty 1984, p. 240). With the emphasis on formal, mathematical modeling, the dynamic aspects of markets that are most closely related to entrepreneurship were largely assumed away (O'Brien 1984) and the firm became modeled simply as a production function (Williamson 1985; Langlois and Foss 1999). In this simplified model of the market, all firms are always on their production possibilities frontiers and always make optimal choices of their input combinations and output levels. There can be no room for entrepreneurship since the firm is but a fully transparent production possibility set and therefore any firm can do what any other firm does (Demsetz 1988b). 
The inadequacy of the traditional theory of the firm explains much of the recent interest in the many theories spawned by Coase's landmark 1937 article, “The Nature of the Firm.” In his article, Coase introduced a fundamentally new way to think about the firm and argued that firms have no reason to exist in the world of neoclassical price theory. Because we observe firms in real life, he reasoned, there must be a "cost to using the price mechanism” (1937, p. 390). Within the firm, the entrepreneur may be able to reduce these "transaction costs" by coordinating productive activities himself. However, internal organization gives rise to other kinds of transaction costs due to problems of information flow, incentives, monitoring, and performance evaluation. The boundary of the firm, then, is determined by the tradeoff, at the margin, between the relative transaction costs of external and internal exchange (Coase 1937; 1988a). Most modern theories of the firm are Coasean in the sense that they adhere to the program established by Coase, even though their terminology, focus, and specific insights may differ.

Coase makes use of the term "entrepreneur” to denote the decision-maker in a firm, but does not share the view of entrepreneurship discussed above. Rather, the Coasean entrepreneur seems to be more engaged in the mechanical exercise of comparing the costs of organizing given transactions in given governance structures than in engaging in future-oriented speculative acts (Boudreaux and Holcombe 1989); he exercises authority through which he "directs" labor factors to "reproduce distribution of factors under atomistic competition within the business unit” (Coase 1988b, p. 4). In this sense, the Coasean entrepreneur is an authoritative imitator in a semi-static setting rather than a judgmental decision-maker as in Knight’s approach.

The firm in modern organizational economics is to a large extent Coasean in that it is viewed as a contractual entity for which the economizing on transaction costs provides the best explanation to its existence, boundaries, and internal organization. Whereas the body of literature addresses all of these three issues, none of the theories in modern organizational economics 
provides a unified framework incorporating transaction costs of the same kind (see e.g. N. J. Foss 1997, p. 175; N. J. Foss and Klein 2008, p. 426; cf. Garrouste and Saussier 2008, p. 23). Indeed, a possible perspective on the division of labor that exists within the modern theory of the firm is that while the principal-agent approach (Jensen and Meckling 1976; Holmström and Milgrom 1991; 1994) and team theory (Alchian and Demsetz 1972; Marschak and Radner 1972) are mainly relevant for understanding internal organization, the transaction cost (Williamson 1975; 1985) and property rights approaches (Grossman and Hart 1986; Hart and Moore 1990; Hart 1995) are designed to explain firm boundaries. Their emphasis on different kinds of transaction costs leads to contractual imperfection, and therefore to economic outcomes inferior to the full-information, zerotransaction-cost ideal, in different ways. While principal-agent theory emphasizes costs of monitoring contractual relationships in light of potential moral hazard, the transaction cost and property rights approaches emphasize the costs of writing (complete) contracts and the costs of adjusting to unanticipated contingencies, respectively. Only transaction cost economics and the property rights approach are conventionally considered theories of the firm, strictly speaking, since the others do not explain the boundaries of the firm in terms of asset ownership (Hart 1995).

Following the former (Williamson 1985; 1996), organizational economics places particular emphasis on specific (or highly complementary) assets in attempting to explain the boundaries of the firm. High asset specificity means that there is a great difference in market value between an asset's present and alternative uses, which suggests investments in such expose agents to potential hazard: once investments are made and contracts are signed, unanticipated changes in circumstances can give rise to costly renegotiation. With the value of the asset being specific to the particular transaction, one party can be "held up" by the other party attempting to extract quasi-rents through threatening to pull out of the arrangement, which would greatly reduce the value of the 
asset. The parties to the transaction may choose to vertically integrate the transaction to eliminate such adversarial interests. Less extreme options include so-called "hybrid” arrangements: long-term contracts, partial ownership, or agreements for both parties to invest in offsetting relationshipspecific investments (Ménard 2010). Overall, parties choose a particular governance structure in order to best control the underinvestment problem, given the particulars of the relationship.

There are many ways in which entrepreneurship, and especially entrepreneurship as judgment, can be incorporated in modern organizational economics. The emphasis put on asset ownership, as well as incomplete contracting, when explaining firm organization accords well with Knight's ([1921] 1985) views, and theories of decision-making under asymmetric information illustrate the distinctiveness of entrepreneurship. Nevertheless, the modern economics of organization is still fully rooted in the neoclassical theoretical framework and has only grafted a super-structure of asymmetric information, transaction costs, and the like on top of the neoclassical theory of production (see e.g. Langlois and Foss 1999; N. J. Foss 1996). While notions of uncertainty, ignorance, and surprise are occasionally invoked in the literature, they serve merely as rhetorical devices to justify the assumption that contracts are incomplete (N. J. Foss 2003) but are not themselves explained. Still, key insights from organizational economics and the concept of entrepreneurial judgment may be usefully joined into a more complete theory of economic organization.

\section{HETEROGENEOUS ASSETS AND ENTREPRENEURIAL OWNERSHIP}

The primary function of the entrepreneur is to choose among the various combinations of inputs suitable for producing particular goods according to his planned structure of production, and attempt to realize his imagined solution to perceived problems through establishing still unrealized (and unheard of) combinations of yet-to-be-created highly specialized factors and assets (Bylund 
2011). In the real world rather than the stylized neoclassical view of the market, this task consists primarily of choosing among combinations of specialized labor factors and heterogeneous capital assets whose “combinations ... will be ever changing, will be dissolved and re-formed” (Lachmann [1956] 1978, p. 13) and guiding these factors toward wanted degrees and types of specialization. Hence, the entrepreneurial problem is extremely complicated and always subject to a high degree of uncertainty (cf. Alvarez and Barney 2005).

Heterogeneous assets can usefully be analyzed in terms of attributes (Barzel 1997) or specificities (Lachmann [1956] 1978), i.e. their characteristics, functions, possible uses, etc., as perceived by the entrepreneur. Heterogeneity exists to the extent that the assets have different, and different levels of, valued attributes, and may vary over time, even for a particular asset (cf. K. Foss et al. 2007). In a world of "Knightian" uncertainty, entrepreneurs are unlikely to know all relevant attributes of all assets when production decisions are made and they also cannot with certainty forecast future attributes of an asset. The latter must be discovered as assets are used in production, which means future attributes are "created" as entrepreneurs envision new ways of using assets to produce goods.

The creation of attributes constitutes an important entrepreneurial function and suggests a distinct role for asset ownership. Since property rights are primarily held over attributes (Barzel 1997; cf. Kim and Mahoney 2007), the role for asset ownership results from gaining property rights to bundles of existing and future attributes. Ownership emerges as a low-cost means of allocating the rights to attributes of assets that are created or discovered by the entrepreneur-owner. Of course, asset ownership itself also provides a powerful incentive to create or discover new attributes, suggesting new opportunities for profit (cf. Alvarez and Barney 2007a), as ownership conveys the 
legally recognized (and at least partly enforced) right to the income of an asset, including the right to income from new attributes.

\section{IMPLICATIONS FOR THE THEORY OF THE FIRM}

As was previously mentioned, there can be only incomplete markets for judgment due to the partial tacitness of this quality. Agents may realize rents from their human capital through three means: (1) selling labor services on market conditions, (2) entering into employment contracts, or (3) starting a firm. As Barzel (1987) argues, moral hazard implies that options (1) and (2) are often inefficient means of realizing rents (cf. Alvarez and Barney 2004). However, there are reasons why the market may not be able to evaluate entrepreneurial services in addition to measurement difficulties and the moral hazard and adverse selection problems that follow. For instance, Kirzner (1979, p. 181) argues that "entrepreneurship reveals to the market what the market did not realize was available" while Casson (1982, p. 14) argues that "the essence of entrepreneurship is being different" especially in terms of "perception of the situation” (cf. Casson 1997). Alvarez and Barney (2005; 2007b; cf. Hitt et al. 2001) take a different approach that builds on both Kirzner and Casson, conceiving entrepreneurs as competing for the appropriation of profit opportunities, both discovered and "created," which often involves creating firms. In these kinds of approaches, non-contractibility arises because “[t]he decisive factors ... are so largely on the inside of the person making the decision that the 'instances' are not amenable to objective description and external control” (Knight [1921] 1985, p. 251; cf. N. J. Foss 1993). The existence of the firm can thus be explained by a specific category of transaction costs, namely, those that close the market for entrepreneurial judgment.

While this suggests a rationale for self-employment as compared to employment, i.e. the creation of one-person firms, we can discern reasons for the emergence of the employment contract 
due to capital (resource) heterogeneity. The entrepreneur acts under uncertainty in terms of the outcome of combining known attributes of heterogeneous capital assets but also regarding how to make best use of attributes discovered in the future. Under such circumstances, knowledge of the optimal sequence or execution of tasks is not likely to exist. Therefore, smaller scale entrepreneurial judgment is required on the task level as well as in the relations between tasks in order to continuously make adjustments to improve productivity and make full use of discovered attributes.

Given the limits of incomplete market contracting, the entrepreneur is better off guiding the continuously evolving system while delegating the detailed experimenting within and between specialized tasks in the established structure of production to individual members of a team of producers. Establishing market contracts in such a situation with measurement difficulties would allow any team member hold-up opportunities and the possibility to veto the guidance from the entrepreneur, thereby risking the profitability of the structure. In other words, in an ever-changing world with heterogeneous capital assets and subject to Knightian uncertainty the entrepreneur is better off creating a trusted and specialized team within the boundaries of the firm. These team members can then exercise derived judgment as proxy-entrepreneurs (K. Foss, Foss and Klein 2007) to experiment with individual tasks in order to optimize productivity while adhering to the ends of the overall structure (for an alternative view, see e.g. Hsieh, Nickerson and Zenger 2007).

The entrepreneur remains in control of the firm through asset ownership, incomplete or open-ended contracting with team members through which they align their skills and effort to the entrepreneur's ends, and superior judgment regarding (and knowledge of) the overall structure of production and the particular ends to be achieved through the imagined and attempted production process. The firm can therefore be seen as a purposefully created structure that enables the entrepreneur to realize an imagined production process that is still inexistent in the market. In fact, 
as Bylund (2011) argues, the firm can be seen as an "island” of super-utilized division of labor that cannot be established in the market through contracting due to incompatibilities with the overall market structure. Integrating the yet-to-be-realized production process in a firm is a means for the entrepreneur to artificially make real his vision for a future market structure; within the firm, the increased density of factors allows them to specialize and co-specialize to the entrepreneur's imagined process in ways and to an extent that is literally impossible outside of the firm.

Furthermore, the firm's boundaries are closely related to the theory of entrepreneurship. Mergers, acquisitions, divestitures, and other reorganizations are best viewed as responses to valuation discrepancies that are perceived, subjectively, by entrepreneurs. One implication is that unprofitable boundary changes should not be viewed as "mistakes," subject to tight regulatory scrutiny (Klein and Klein 2001). A divestiture of previously acquired assets, for example, may mean simply that profit-seeking entrepreneurs have updated their forecasts of future conditions or otherwise learned from experience. Boundary changes can be viewed as a form of organizational experimentation (Mosakowski 1997; Boot, Milbourn and Thakor 1999; Matsusaka 2001) in which entrepreneurs seek to discover their own capabilities by trying various combinations of activities, which could include diversifying into new industries. However, while the long-term success or failure of acquisitions cannot, in general, be predicted by measures of manager control or principalagent problems (Klein and Klein 2001), significantly higher rates of divestiture tend to occur in a clusters of mergers (see e.g. Mitchell and Mulherin 1996; Andrade, Mitchell and Stafford 2001; Andrade and Stafford 2004). As suggested in the literature, mergers may be driven in part by industry-specific factors, such as regulatory shocks, which means that when regulation of an industry changes, economic calculation becomes more difficult, and entrepreneurial activity is hampered. 
Entrepreneurs also experiment with internal organization..Whereas entrepreneurship activity is usually described as socially beneficial (Mises 1949; Kirzner 1973), some forms may be “destructive” (Baumol 1990; Holcombe 2002; cf. Coyne, Sobel and Dove 2010). Entrepreneurship may be socially harmful if it consumes resources and brings about a social loss; discovering new forms of moral hazard (Holmström 1982), creating hold-ups (Williamson 1996), and inventing new ways of engaging in rent-seeking activities relative to government (Baumol 1990; Holcombe 2002) are examples of destructive entrepreneurship. In contrast, “productive” entrepreneurship refers to the creation or discovery of new attributes leading to an increase in joint surplus. The firm and the entrepreneur may be victimized by employees engaging in destructive entrepreneurial activities. Therefore, the internal organization of the firm should aim to control destructive and support productive entrepreneurial activities (Foss, Foss, and Klein, 2007).

To control destructive entrepreneurship, the firm should be organized to balance the costs of destructive entrepreneurship and costs of monitoring and curbing such behavior, as employees may attempt to creatively circumvent constraints thereby imposing extra costs on the organization. Imposed constraints may have the unwanted side effect that productive entrepreneurship is stifled (see Kirzner 1985), and, more generally, imposing (too many) constraints on employees may reduce their propensity to create or discover new attributes of productive assets. Relaxing such constraints in order to stimulate productive creation and discovery of new attributes may result in less completely specified principal-agent relationships, thereby giving agents opportunities to exercise their own, often far reaching, judgments. This may also permit potentially destructive entrepreneurship and managing the tradeoff between productive and destructive entrepreneurship becomes a critical management task. 
In this context, asset ownership is important through giving entrepreneurs the right to choose their own preferred tradeoffs. Briefly stated, ownership allows the employer-entrepreneur's preferred degree of contractual incompleteness - and therefore a certain combination of productive and destructive entrepreneurship — to be implemented at low cost. This function of ownership is particularly important in a dynamic market process, the kind stressed by Knight (in the later chapters of [1921] 1985) and the Austrians (Hayek 1948; Kirzner 1973; Littlechild 1986). In such a context, an ongoing process of judgmental decision-making requires contractual constraints to address the changing tradeoffs between productive and destructive entrepreneurship inside the firm. The power conferred by ownership allows the employer-entrepreneur to do this at low cost (for a fuller analysis, see K. Foss and Foss 2002).

\section{CONCLUSION}

The theory of entrepreneurship and the economic theory of the firm thus have much to learn from each other. We have argued that the concept of entrepreneurship as judgment provides the clearest link between entrepreneurship, asset ownership, and economic organization. Similarly, the economic theory of the firm can be improved substantially by taking seriously the essential heterogeneity of capital goods and the subsequent need for entrepreneurial experimentation.

However, because these concepts lie fundamentally outside the standard constrained optimization framework, they are inherently difficult to model mathematically. Since modern economists have difficulty appreciating ideas that are not expressed in this familiar language, it may prove difficult to get the aforementioned insights incorporated into the economic theory of the firm. However, recent theoretical advances in strategic entrepreneurship and attempts to bridge the divide through studying entrepreneurial firms make us cautiously optimistic. We may see considerable advances in economists' understanding of the firm in a not too distant future. 


\section{REFERENCES}

Alchian, Armen A. and Harold Demsetz (1972), "Production, Information Costs and Economic Organization," American Economic Review 62(5), pp. 777-795.

Alvarez, Sharon A. and Jay B. Barney (2004), "Organizing Rent Generation and Appropriation: Toward a Theory of the Entrepreneurial Firm," Journal of Business Venturing 19, pp. 621635.

(2005), "How Do Entrepreneurs Organize Firms under Conditions of Uncertainty?," Journal of Management 31(5), pp. 776-793.

(2007a), "Discovery and Creation: Alternative Theories of Entrepreneurial Action," Strategic Entrepreneurship Journal 1(1-2), pp. 11-26.

(2007b), "The Entrepreneurial Theory of the Firm," Journal of Management Studies 44(7), pp. 1057-1063.

Andrade, Gregor; Mark Mitchell and Erik Stafford (2001), "New Evidence and Perspectives on Mergers," Journal of economic perspectives 15, pp. 103-120.

Andrade, Gregor and Erik Stafford (2004), "Investigating the Economic Role of Mergers," Journal of Corporate Finance 10, pp. 1-36.

Barzel, Yoram (1987), "The Entrepreneur's Reward for Self-Policing," Economic Inquiry 25, pp. 103-116.

(1997), Economic Analysis of Property Rights, Cambridge: Cambridge University Press.

Baumol, William J. (1990), "Entrepreneurship: Productive, Unproductive, and Destructive," Journal of political economy 98, pp. 893-919.

Boot, Arnoud W.A.; Todd T. Milbourn and Anjan V. Thakor (1999), "Megamergers and Expanded Scope: Theories of Bank Size and Activity Diversity," Journal of Banking and Finance 23, pp. 195-214.

Boudreaux, Donald J. and Randall G. Holcombe (1989), "The Coasian and Knightian Theories of the Firm," Managerial and Decision Economics 10(2), pp. 147-154.

Bylund, Per L. (2011), "Division of Labor and the Firm: An Austrian Attempt at Explaining the Firm in the Market," Quarterly Journal of Austrian Economics forthcoming.

Cantillon, Richard ([1755] 2010), An Essay on Economic Theory, Auburn, Al.: Ludwig von Mises Institute.

Casson, Mark C. (1982), The Entrepreneur: An Economic Theory, Rowman \& Littlefield Pub Inc. (1997), Information and Organization: A New Perspective on the Theory of the Firm, Oxford: Clarendon Press. 
(2000), "An Entrepreneurial Theory of the Firm," In Competence, Governace and Entrepreneurship: Advances in Economic Strategy Research, ed. N. J. Foss. New York: Oxford University Press.

Coase, Ronald H. (1937), "The Nature of the Firm," Economica 4(16), pp. 386-405.

(1988a), "The Nature of the Firm: Meaning," Journal of Law, Economics \& Organization 4(1), pp. 19-32.

(1988b), "The Nature of the Firm: Origin," Journal of Law, Economics \& Organization 4(1), pp. 3-17.

Coyne, Christopher J.; Russell S. Sobel and John A. Dove (2010), "The Non-Productive Entrepreneurial Process," Review of Austrian Economics 23(4), pp. 333-346.

Demsetz, Harold (1983), "The Neglect of the Entrepreneur," In Entrepreneurship, ed. J. Ronen. Lexington: Lexington Press.

(1988a), "Profit as a Functional Return: Reconsidering Knight's Views," In Ownership, Control and the Firm. The Organization of Economic Activity, Vol. 1, ed. H. Demsetz. Oxford: Blackwell.

(1988b), "The Theory of the Firm Revisited," Journal of Law, Economics, and Organization 4(1), pp. 141-161.

Foss, Kirsten and Nicolai J. Foss (2002), "Economic Organization and the Trade-Offs between Productive and Destructive Entrepreneurship," In Entrepreneurship and the Firm: Austrian Perspectives on Economic Organization, ed. N. J. Foss and P. G. Klein, 102-127. Cheltenham: Edward Elgar.

Foss, Kirsten; Nicolai J. Foss and Peter G. Klein (2007), "Original and Derived Judgment: An Entrepreneurial Theory of Economic Organization," Organization Studies 28(12), pp. 1-20.

Foss, Kirsten; Nicolai J. Foss; Peter G. Klein and Sandra K. Klein (2007), "The Entrepreneurial Organization of Heterogeneous Capital," Journal of Management Studies 44(7), pp. 11651186.

Foss, Nicolai J. (1993), "More on Knight and the Theory of the Firm," Managerial and Decision Economics, pp. 269-276.

(1996), "Capabilities and the Theory of the Firm," Revue D'Économie Industrielle (77), pp. 728.

(1997), "Austrian Insights and the Theory of the Firm," In Advances in Austrian Economics, Volume 4, ed. P. J. Boettke and S. Horwitz, 175-198. JAI Press.

(2003), "Herbert Simon's Grand Theme in the Economics of Organization: 'Much Cited and Little Used'," Journal of Economic Psychology 24, pp. 245-264.

Foss, Nicolai J. and Peter G. Klein (2005), "Entrepreneurship and the Economic Theory of the Firm: Any Gains from Trade?," In Handbook of Entrepreneurship: Disciplinary Perspectives, ed. R. Agarwal, S. A. Alvarez and O. Sorenson, 55-80. New York: Springer.

(2008), "The Theory of the Firm and Its Critics: A Stocktaking and Assessment," In New Institutional Economics: A Guidebook, ed. É. Brousseau and J.-M. Glachant, 425-442. Cambridge: Cambridge University Press. 
(2011), Entrepreneurial Judgment and the Theory of the Firm, Cambridge: Cambridge University Press.

(forthcoming), "Entrepreneurial Alertness and Opportunity Discovery: Origins, Attributes, Critique," In The Historical Foundations of Entrepreneurship Research, ed. H. Landström and F. Lohrke. Aldershot, U.K.: Edward Elgar.

Garrouste, Pierre and Stéphane Saussier (2008), "The Theories of the Firm," In New Institutional Economics: A Guidebook, ed. É. Brousseau and J.-M. Glachant, 23-36. Cambridge: Cambridge University Press.

Grossman, Sanford J. and Oliver D. Hart (1986), "The Costs and Benefits of Ownership: A Theory of Vertical and Lateral Integration," The Journal of Political Economy 94(4), pp. 691-719.

Hart, Oliver D. (1995), Firms, Contracts and Financial Structure, Oxford: Clarendon Press.

Hart, Oliver D. and John Moore (1990), "Property Rights and the Nature of the Firm," Journal of political economy 98(6), pp. 1119-1158.

Hayek, Friedrich A. von (1948), Individualism and Economic Order, Chicago: University of Chicago Press.

Hitt, Michael A.; R. Duane Ireland; S. Michael Camp and Donald L. Sexton (2001), "Strategic Entrepreneurship: Entrepreneurial Strategies for Wealth Creation," Strategic Management Journal 22, pp. 479-491.

Holcombe, Randall G (2002), "Political Entrepreneurship and the Democratic Allocation of Economic Resources," Review of Austrian Economics 15(2), pp. 143-159.

Holmström, Bengt (1982), "Moral Hazard in Teams," Bell Journal of Economics 13(2), pp. 324340.

Holmström, Bengt and Paul R. Milgrom (1991), "Multitask Principal-Agent Analysis: Incentive Contracts, Asset Ownership and Job Design," Journal of Law, Economics \& Organization 7, pp. 24-54.

(1994), "The Firm as an Incentive System," The American Economic Review 84(4), pp. 972991.

Hsieh, Chihmao; Jackson Nickerson and Todd R. Zenger (2007), "Opportunity Discovery, Problem Solving, and a Theory of the Entrepreneurial Firm," Journal of Management Studies 44(7), pp. 1255-1277.

Jensen, Michael C. and William H. Meckling (1976), "Theory of the Firm: Managerial Behavior, Agency Costs, and Capital Structure," Journal of financial economics 3(4), pp. 305-360.

Kim, Jongwook and Joseph T. Mahoney (2007), "Appropriating Economic Rents from Resources: An Integrative Property Rights and Resource-Based Approach," International Journal of Learning and Intellectual Capital 4(1/2), pp. 11-28.

Kirzner, Israel M. (1973), Competition and Entrepreneurship, Chicago: University of Chicago Press. 
(1979), Perception, Opportunity, and Profit: Studies in the Theory of Entrepreneurship, Chicago: University of Chicago Press.

(1985), Discovery and the Capitalist Process, University of Chicago Press Chicago, IL.

(1992), The Meaning of the Market Process, London: Routledge.

(2009), "The Alert and Creative Entrepreneur: A Clarification," Small Business Economics 32(2), pp. 145-152.

Klein, Peter G. (2008), "Opportunity Discovery, Entrepreneurial Action, and Economic Organization," Strategic Entrepreneurship Journal 2(3), pp. 175-190.

Klein, Peter G. and Sandra K. Klein (2001), "Do Entrepreneurs Make Predictable Mistakes? Evidence from Corporate Divestitures," Quarterly Journal of Austrian Economics 4, pp. 3-25.

Knight, Frank H. (1942), "Profit and Entrepreneurial Functions," The Journal of Economic History 2(2), pp. 126-132.

([1921] 1985), Risk, Uncertainty and Profit, Chicago: University of Chicago Press.

Lachmann, Ludwig M. ([1956] 1978), Capital and Its Structure, Kansas City: Sheed Andrews and McMeel.

Langlois, Richard N. and Metin M. Cosgel (1993), "Frank Knight on Risk, Uncertainty, and the Firm: A New Interpretation," Economic Inquiry 31(3), pp. 456-465.

Langlois, Richard N. and Nicolai J. Foss (1999), "Capabilities and Governance: The Rebirth of Production in the Theory of Economic Organization," Kyklos 52(2), pp. 201-218.

Littlechild, Stephen C. (1986), "Three Types of Market Process," In Economics as a Process, ed. R. N. Langlois. Cambridge: Cambridge University Press.

Marschak, Jacob and Roy Radner (1972), Economic Theory of Teams, New Haven: Yale University Press.

Matsusaka, John G. (2001), "Corporate Diversification, Value Maximization, and Organizational Capabilities," Journal of Business 74, pp. 409-431.

McNulty, Paul (1984), "On the Nature and Theory of Economic Organization: The Role of the Firm Reconsidered," History of Political Economy 16, pp. 223-253.

Ménard, Claude (2010), "Hybrid Organisations," In The Elgar Companion to Transaction Cost Economics, ed. N. J. Foss and P. G. Klein, 176-184. Aldershott, UK: Edward Elgar.

Milgrom, Paul R. and John Roberts (1992), Economics of Organization and Management, Englewood Cliffs, $\mathrm{Nj} .:$ Prentice-Hall.

Mises, Ludwig von (1949), Human Action: A Treatise on Economics, New Haven, CN: Yale University Press.

Mitchell, Mark and J. Harold Mulherin (1996), "The Impact of Industry Shocks on Takeover and Restructuring Activity," Journal of financial economics 41, pp. 193-229.

Mosakowski, Elaine (1997), "Strategy Making under Causal Ambiguity: Conceptual Issues and Empirical Evidence," Organization Science 8, pp. 414-442. 
O'Brien, Denis P. (1984), "The Evolution of the Theory of the Firm," In Firms, Organization and Labour: Approaches to the Economics of Work Organization, ed. F. H. Stephen, 25-62. London: MacMillan.

Rothbard, Murray N. ([1985] 1997), "Professor Hébert on Entrepreneurship," In The Logic of Action Two: Applications and Criticism from the Austrian School, ed. M. N. Rothbard, 245253. Aldershott, U.K.: Edward Elgar.

Salerno, Joseph T. (1993), "Mises and Hayek Dehomogenized," Review of Austrian Economics 6(2), pp. 113-146.

Schumpeter, Joseph A. ([1911] 1934), The Theory of Economic Development: An Inquiry into Profi Ts, Capital, Credit, Interest, and the Business Cycle, Cambridge, MA.: Harvard University Press.

Shane, Scott and S. Venkataraman (2000), "The Promise of Entrepreneurship as a Field of Research," Academy of Management Review 25(1), pp. 217-226.

Williamson, Oliver E. (1975), Markets and Hierarchies, Analysis and Antitrust Implications: A Study in the Economics of Internal Organization, Free Press. (1985), The Economic Institutions of Capitalism, New York: Free Press. (1996), The Mechanisms of Governance, Oxford University Press.

Witt, Ulrich (1998), "Imagination and Leadership: The Neglected Dimension of an Evolutionary Theory of the Firm," Journal of Economic Behavior \& Organization 35, pp. 161-177.

(1999), "Do Entrepreneurs Need Firms? A Contribution to a Missing Chapter in Austrian Economics," Review of Austrian Economics 11(1-2), pp. 99-109. 


\section{SMG - Working Papers \\ www.cbs.dk/smg \\ 2003}

2003-1: Nicolai J. Foss, Kenneth Husted, Snejina Michailova, and Torben Pedersen: Governing Knowledge Processes: Theoretical Foundations and Research Opportunities.

2003-2: Yves Doz, Nicolai J. Foss, Stefanie Lenway, Marjorie Lyles, Silvia Massini, Thomas P. Murtha and Torben Pedersen: Future Frontiers in International Management Research: Innovation, Knowledge Creation, and Change in Multinational Companies.

2003-3: Snejina Michailova and Kate Hutchings: The Impact of In-Groups and OutGroups on Knowledge Sharing in Russia and China CKG Working Paper.

2003-4: Nicolai J. Foss and Torben Pedersen: The MNC as a Knowledge Structure: The Roles of Knowledge Sources and Organizational Instruments in MNC Knowledge Management CKG Working Paper.

2003-5: Kirsten Foss, Nicolai J. Foss and Xosé H. Vázquez-Vicente: “Tying the Manager's Hands": How Firms Can Make Credible Commitments That Make Opportunistic Managerial Intervention Less Likely CKG Working Paper.

2003-6: Marjorie Lyles, Torben Pedersen and Bent Petersen: Knowledge Gaps: The Case of Knowledge about Foreign Entry.

2003-7: Kirsten Foss and Nicolai J. Foss: The Limits to Designed Orders: Authority under "Distributed Knowledge" CKG Working Paper.

2003-8: Jens Gammelgaard and Torben Pedersen: Internal versus External Knowledge Sourcing of Subsidiaries - An Organizational Trade-Off.

2003-9: Kate Hutchings and Snejina Michailova: Facilitating Knowledge Sharing in Russian and Chinese Subsidiaries: The Importance of Groups and Personal Networks Accepted for publication in Journal of Knowledge Management.

2003-10: Volker Mahnke, Torben Pedersen and Markus Verzin: The Impact of Knowledge Management on MNC Subsidiary Performance: the Role of Absorptive Capacity CKG Working Paper.

2003-11: Tomas Hellström and Kenneth Husted: Mapping Knowledge and Intellectual Capital in Academic Environments: A Focus Group Study Accepted for publication in Journal of Intellectual Capital CKG Working Paper.

2003-12: Nicolai J Foss: Cognition and Motivation in the Theory of the Firm: Interaction or "Never the Twain Shall Meet"? Accepted for publication in Journal des Economistes et des Etudes Humaines CKG Working Paper.

2003-13: Dana Minbaeva and Snejina Michailova: Knowledge Transfer and Expatriation Practices in MNCs: The Role of Disseminative Capacity.

2003-14: Christian Vintergaard and Kenneth Husted: Enhancing Selective Capacity Through Venture Bases. 


\section{4}

2004-1: Nicolai J. Foss: Knowledge and Organization in the Theory of the Multinational Corporation: Some Foundational Issues

2004-2: Dana B. Minbaeva: HRM Practices and MNC Knowledge Transfer

2004-3: Bo Bernhard Nielsen and Snejina Michailova: Toward a Phase-Model of Global Knowledge Management Systems in Multinational Corporations

2004-4: Kirsten Foss \& Nicolai J Foss: The Next Step in the Evolution of the RBV: Integration with Transaction Cost Economics

2004-5: Teppo Felin \& Nicolai J. Foss: Methodological Individualism and the Organizational Capabilities Approach

2004-6: Jens Gammelgaard, Kenneth Husted, Snejina Michailova: Knowledge-sharing Behavior and Post-acquisition Integration Failure

2004-7: Jens Gammelgaard: Multinational Exploration of Acquired R\&D Activities

2004-8: Christoph Dörrenbächer \& Jens Gammelgaard: Subsidiary Upgrading? Strategic Inertia in the Development of German-owned Subsidiaries in Hungary

2004-9: Kirsten Foss \& Nicolai J. Foss: Resources and Transaction Costs: How the Economics of Property Rights Furthers the Resource-based View

2004-10: Jens Gammelgaard \& Thomas Ritter: The Knowledge Retrieval Matrix: Codification and Personification as Separate Strategies

2004-11: Nicolai J. Foss \& Peter G. Klein: Entrepreneurship and the Economic Theory of the Firm: Any Gains from Trade?

2004-12: Akshey Gupta \& Snejina Michailova: Knowledge Sharing in Knowledge-Intensive Firms: Opportunities and Limitations of Knowledge Codification

2004-13: Snejina Michailova \& Kate Hutchings: Knowledge Sharing and National Culture: A Comparison Between China and Russia

\section{5}

2005-1: Keld Laursen \& Ammon Salter: My Precious - The Role of Appropriability Strategies in Shaping Innovative Performance

2005-2: Nicolai J. Foss \& Peter G. Klein: The Theory of the Firm and Its Critics: A Stocktaking and Assessment

2005-3: Lars Bo Jeppesen \& Lars Frederiksen: Why Firm-Established User Communities Work for Innovation: The Personal Attributes of Innovative Users in the Case of Computer-Controlled Music

2005-4: Dana B. Minbaeva: Negative Impact of HRM Complementarity on Knowledge Transfer in MNCs

2005-5: Kirsten Foss, Nicolai J. Foss, Peter G. Klein \& Sandra K. Klein: Austrian Capital 
Theory and the Link Between Entrepreneurship and the Theory of the Firm

2005-1: Nicolai J. Foss: The Knowledge Governance Approach

2005-2: Torben J. Andersen: Capital Structure, Environmental Dynamism, Innovation Strategy, and Strategic Risk Management

2005-3: Torben J. Andersen: A Strategic Risk Management Framework for Multinational Enterprise

2005-4: Peter Holdt Christensen: Facilitating Knowledge Sharing: A Conceptual Framework

2005-5 Kirsten Foss \& Nicolai J. Foss: Hands Off! How Organizational Design Can Make Delegation Credible

2005-6 Marjorie A. Lyles, Torben Pedersen \& Bent Petersen: Closing the Knowledge Gap in Foreign Markets - A Learning Perspective

2005-7 Christian Geisler Asmussen, Torben Pedersen \& Bent Petersen: How do we Capture "Global Specialization" when Measuring Firms' Degree of internationalization?

2005-8 Kirsten Foss \& Nicolai J. Foss: Simon on Problem-Solving: Implications for New Organizational Forms

2005-9 Birgitte Grøgaard, Carmine Gioia \& Gabriel R.G. Benito: An Empirical Investigation of the Role of Industry Factors in the Internationalization Patterns of Firms

2005-10 Torben J. Andersen: The Performance and Risk Management Implications of Multinationality: An Industry Perspective

2005-11 Nicolai J. Foss: The Scientific Progress in Strategic Management: The case of the Resource-based view

2005-12 Koen H. Heimeriks: Alliance Capability as a Mediator Between Experience and Alliance Performance: An Empirical Investigation Into the Alliance Capability Development Process

2005-13 Koen H. Heimeriks, Geert Duysters \& Wim Vanhaverbeke: Developing Alliance Capabilities: An Empirical Study

2005-14 JC Spender: Management, Rational or Creative? A Knowledge-Based Discussion

\section{6}

2006-1: Nicolai J. Foss \& Peter G. Klein: The Emergence of the Modern Theory of the Firm

2006-2: Teppo Felin \& Nicolai J. Foss: Individuals and Organizations: Thoughts on a Micro-Foundations Project for Strategic Management and Organizational Analysis

2006-3: Volker Mahnke, Torben Pedersen \& Markus Venzin: Does Knowledge Sharing 
Pay? An MNC Subsidiary Perspective on Knowledge Outflows

2006-4: Torben Pedersen: Determining Factors of Subsidiary Development

2006-5 Ibuki Ishikawa: The Source of Competitive Advantage and Entrepreneurial Judgment in the RBV: Insights from the Austrian School Perspective

2006-6 Nicolai J. Foss \& Ibuki Ishikawa: Towards a Dynamic Resource-Based View: Insights from Austrian Capital and Entrepreneurship Theory

2006-7 Kirsten Foss \& Nicolai J. Foss: Entrepreneurship, Transaction Costs, and Resource Attributes

2006-8 Kirsten Foss, Nicolai J. Foss \& Peter G. Klein: Original and Derived Judgement: An Entrepreneurial Theory of Economic Organization

2006-9 Mia Reinholt: No More Polarization, Please! Towards a More Nuanced Perspective on Motivation in Organizations

2006-10 Angelika Lindstrand, Sara Melen \& Emilia Rovira: Turning social capital into business? A study of Swedish biotech firms' international expansion

2006-11 Christian Geisler Asmussen, Torben Pedersen \& Charles Dhanaraj: Evolution of Subsidiary Competences: Extending the Diamond Network Model

2006-12 John Holt, William R. Purcell, Sidney J. Gray \& Torben Pedersen: Decision Factors Influencing MNEs Regional Headquarters Location Selection Strategies

2006-13 Peter Maskell, Torben Pedersen, Bent Petersen \& Jens Dick-Nielsen: Learning Paths to Offshore Outsourcing - From Cost Reduction to Knowledge Seeking

2006-14 Christian Geisler Asmussen: Local, Regional or Global? Quantifying MNC Geographic Scope

2006-15 Christian Bjørnskov \& Nicolai J. Foss: Economic Freedom and Entrepreneurial Activity: Some Cross-Country Evidence

2006-16 Nicolai J. Foss \& Giampaolo Garzarelli: Institutions as Knowledge Capital: Ludwig M. Lachmann's Interpretative Institutionalism

2006-17 Koen H. Heimriks \& Jeffrey J. Reuer: How to Build Alliance Capabilities

2006-18 Nicolai J. Foss, Peter G. Klein, Yasemin Y. Kor \& Joseph T. Mahoney: Entrepreneurship, Subjectivism, and the Resource - Based View: Towards a New Synthesis

2006-19 Steven Globerman \& Bo B. Nielsen: Equity Versus Non-Equity International Strategic Alliances: The Role of Host Country Governance

\section{7}

2007-1 Peter Abell, Teppo Felin \& Nicolai J. Foss: Building Micro-Foundations for the Routines, Capabilities, and Performance Links 
2007-2 Michael W. Hansen, Torben Pedersen \& Bent Petersen: MNC Strategies and Linkage Effects in Developing Countries

2007-3 Niron Hashai, Christian G. Asmussen, Gabriel R.G. Benito \& Bent Petersen: Predicting the Diversity of Foreign Entry Modes

2007-4 Peter D. Ørberg Jensen \& Torben Pedersen: Whether and What to Offshore?

2007-5 Ram Mudambi \& Torben Pedersen: Agency Theory and Resource Dependency Theory: Complementary Explanations for Subsidiary Power in Multinational Corporations

2007-6 Nicolai J. Foss: Strategic Belief Management

2007-7 Nicolai J. Foss: Theory of Science Perspectives on Strategic Management Research: Debates and a Novel View

2007-8 Dana B. Minbaeva: HRM Practices and Knowledge Transfer in MNCs

2007-9 Nicolai J. Foss: Knowledge Governance in a Dynamic Global Context: The Center for Strategic Management and Globalization at the Copenhagen Business School

2007-10 Paola Gritti \& Nicolai J. Foss: Customer Satisfaction and Competencies: An Econometric Study of an Italian Bank

2007-11 Nicolai J. Foss \& Peter G. Klein: Organizational Governance

2007-12 Torben Juul Andersen \& Bo Bernhard Nielsen: The Effective Ambidextrous Organization: A Model of Integrative Strategy Making Processes.

\section{8}

2008-1 Kirsten Foss \& Nicolai J. Foss: Managerial Authority When Knowledge is Distributed: A Knowledge Governance Perspective

2008-2 Nicolai J. Foss: Human Capital and Transaction Cost Economics.

2008-3 Nicolai J. Foss \& Peter G. Klein: Entrepreneurship and Heterogeneous Capital.

2008-4 Nicolai J. Foss \& Peter G. Klein: The Need for an Entrepreneurial Theory of the Firm.

2008-5 Nicolai J. Foss \& Peter G. Klein: Entrepreneurship: From Opportunity Discovery to Judgment.

2008-6 Mie Harder: How do Rewards and Management Styles Influence the Motivation to Share Knowledge?

2008-7 Bent Petersen, Lawrence S. Welch \& Gabriel R.G. Benito: Managing the Internalisation Process - A Theoretical Perspective.

2008-8 Torben Juul Andersen: Multinational Performance and Risk Management Effects: Capital Structure Contingencies. 
2008-9 Bo Bernard Nielsen: Strategic Fit and the Role of Contractual and Procedural Governance in Alliances: A Dynamic Perspective.

2008-10 Line Gry Knudsen \& Bo Bernhard Nielsen: Collaborative Capability in R\&D Alliances: Exploring the Link between Organizational and Individual level Factors.

2008-11 Torben Juul Andersen \& Mahesh P. Joshi: Strategic Orientations of Internationalizing Firms: A Comparative Analysis of Firms Operating in Technology Intensive and Common Goods Industries.

2008-12 Dana Minbaeva: HRM Practices Affecting Extrinsic and Intrinsic Motivation of Knowledge Receivers and their Effect on Intra-MNC Knowledge Transfer.

2008-13 Steen E. Navrbjerg \& Dana Minbaeva: HRM and IR in Multinational Corporations: Uneasy Bedfellows?

2008-14 Kirsten Foss \& Nicolai J. Foss: Hayekian Knowledge Problems in Organizational Theory.

2008-15 Torben Juul Andersen: Multinational Performance Relationships and Industry Context.

2008-16 Larissa Rabbiosi: The Impact of Subsidiary Autonomy on MNE Knowledge Transfer: Resolving the Debate.

2008-17 Line Gry Knudsen \& Bo Bernhard Nielsen: Organizational and Individual Level Antecedents of Procedural Governance in Knowledge Sharing Alliances.

2008-18 Kirsten Foss \& Nicolai J. Foss: Understanding Opportunity Discovery and Sustainable Advantage: The Role of Transaction Costs and Property Rights.

2008-19 Teppo Felin \& Nicolai J. Foss: Social Reality, The Boundaries of Self-fulfilling Prophecy, and Economics.

2008-20 Yves Dos, Nicolai J. Foss \& José Santos: A Knowledge System Approach to the Multinational Company: Conceptual Grounding and Implications for Research

2008-21 Sabina Nielsen \& Bo Bernhard Nielsen: Why do Firms Employ foreigners on Their Top Management Teams? A Multi-Level Exploration of Individual and Firm Level Antecedents

2008-22 Nicolai J. Foss: Review of Anders Christian Hansen's “Uden for hovedstrømmen - Alternative strømninger i økonomisk teori"

2008-23 Nicolai J. Foss: Knowledge, Economic Organization, and Property Rights

2008-24 Sjoerd Beugelsdijk, Torben Pedersen \& Bent Petersen: Is There a Trend Towards Global Value Chain Specialization? - An Examination of Cross Border Sales of US Foreign Affiliates 
2008-25 Vikas Kumar, Torben Pedersen \& Alessandro Zattoni: The performance of business group firms during institutional transition: A longtitudinal study of Indian firms

2008-26 Sabina Nielsen \& Bo B. Nielsen: The effects of TMT and Board Nationality Diversity and Compensation on Firm Performance

2008-27 Bo B. Nielsen \& Sabina Nielsen: International Diversification Strategy and Firm Performance: A Multi-Level Analysis of Firm and Home Country Effects

\section{9}

2009-1 Nicolai J. Foss: Alternative Research Strategies in the Knowledge Movement: From Macro Bias to Micro-Foundations and Multi-Level Explanation

2009-2 Nicolai J. Foss \& Peter G. Klein: Entrepreneurial Alertness and Opportunity Discovery: Origins, Attributes, Critique

2009-3 Nicolai J. Foss \& Dana B. Minbaeva: Governing Knowledge: The Strategic Human Resource Management Dimension

2009-4 Nils Stieglitz \& Nicolai J. Foss: Opportunities and New Business Models: Transaction Cost and Property Rights Perspectives on Entrepreneurships

2009-5 Torben Pedersen: Vestas Wind Systems A/S: Exploiting Global R\&D Synergies

2009-6 Rajshree Agarwal, Jay B. Barney, Nicolai J. Foss \& Peter G. Klein: Heterogeneous Resources and the Financial Crisis: Implications of Strategic Management Theory

2009-7 Jasper J. Hotho: A Measure of Comparative Institutional Distance

2009-8 Bo B. Nielsen \& Sabina Nielsen: The Impact of Top Management Team Nationality Diversity and International Experience on Foreign Entry Mode

2009-9 Teppo Felin \& Nicolai Juul Foss: Experience and Repetition as Antecedents of Organizational Routines and Capabilities: A Critique of Behaviorist and Empiricist Approaches

2009-10 Henk W. Volberda, Nicolai J. Foss \& Marjorie E. Lyles: Absorbing the Concept of Absorptive Capacity: How To Realize Its Potential in the Organization Field

2009-11 Jan Stentoft Arlbjørn, Brian Vejrum Wæhrens, John Johansen \& Torben Pedersen: Produktion i Danmark eller offshoring/outsourcing: Ledelsesmæssige udfordringer 


\section{0}

2010-1 Dana B. Minbaeva, Kristiina Mäkelä \& Larissa Rabbiosi: Explaining Intraorganizational Knowledge Transfer at the Individual Level

2010-2 Dana B.Minbaeva \& Torben Pedersen: Governing Individual Knowledge Sharing Behavior

2010-3 Nicolai J. Foss \& Peter G. Klein: Alertness, Judgment, and the Antecedents of Entrepreneurship

2010-4 Nicolai J.Foss \& Joseph T.Mahoney: Exploring Knowledge Governance

2010-5 Jasper J. Hotho, Florian Becker-Ritterspach \& Ayse Saka-Helmhout: Enriching Absorptive Capacity Through Social Interaction

2010-6 Nicolai J. Foss \& Bo B. Nielsen: Researching Collaborative Advantage: Some Conceptual and Multi-level Issues

2010-7 Nicolai J. Foss \& Nils Stieglitz: Modern Resource-Based Theory(ies)

2010-8 Christian Bjørnskov \& Nicolai J. Foss: Do Economic Freedom and Entrepreneurship Impact Total Factor Productivity?

2010-9 Gabriel R.G. Benito, Bent Petersen \& Lawrence S. Welch: Mode Combinations and International Operations: Theoretical Issues and an Empirical Investigation

\section{1}

2011-1 Peter D. Ørberg Jensen \& Bent Petersen: Human Asset Internalization and Global Sourcing of Services - A Strategic Management Analysis on Activity-level

2011-2 Mie Harder: Management Innovation Capabilities: A Typology and Propositions for Management Innovation Research

2011-3 Mie Harder: Internal Antecedents of Management Innovation: The effect of diagnostic capability and implementation capability 
2011-4 Mie Harder: Explaining Management Innovation Pervasiveness: The Role of Internal Antecedents

2011-5 Mie Harder: Internal Determinants of Product Innovation and Management Innovation: The Effect of Diagnostic Capability and Implementation Capability

2011-6 Nicolai J. Foss, Peter G. Klein \& Per L. Bylund: Entrepreneurship and the Economics of the Firm 